\title{
A ORGANIZAÇÃO TERRITORIAL DA PROVÍNCIA DE SALAMANCA
}

SUZANNE DAVEAU ${ }^{1}$

O Departamento de Geografia da Universidade de Salamanca acaba de produzir um magnífico e excelente livro, consagrado à apresentação da província de Salamanca e das suas divisões comarcais ${ }^{2}$. Magnífico, por se tratar de um álbum com grande qualidade técnica, de $23 \times 30 \mathrm{~cm}$, óptimos papel e encadernação, profusa e linda ilustração cartográfica e fotográfica, que torna este livro um prazer para os olhos e uma premente incitação a descobrir ou a recordar as nobres paisagens da vizinha província. Excelente, por constituir um documento de grande clareza e riqueza científica sobre a organização e o conteúdo regional salmantino, e sobre a sua recente evolução, encarados segundo "os modelos seculares de adaptação às condições naturais, à crise da agricultura tradicional com as sequelas do êxodo rural, e às novas formas de ocupação do solo." O trabalho foi dirigido e coordenado pelo Prof. Valentín CABERo DiÉGUEZ, com a ajuda do Prof. José Manuel Llorente PinTo. Reúne a participação de 27 autores, todos docentes ou discentes do Departamento de Geografia de Salamanca. A Cartografia é do Prof. José Ignacio IZQUIERDo MisIEGo e as notáveis fotografias são devidas a Albino López Pedraza.

O livro abre com um mapa-índice, que localiza as divisões comarcais utilizadas e os correspondentes capítulos, evidenciando logo a organização da obra: 3 capítulos sobre o conjunto da província e 31 dedicados às 12 comarcas e respectivos centros urbanos. A cada comarca correspondem 1 ou 2 capítulos, a cada vila ou cidade, entre menos de 1 e 4 capítulos, caso da capital de província, apresentada no fim do livro. Em anexo, encontram-se localizados e nomeados os 362 municípios da província, o que permite, graças aos numerosos mapas e quadros comarcais, uma leitura de pormenor até esta escala ou, mesmo, até ao nível dos lugares habitados (as entidades dos censos), para os quais é indicada a população em 1950 e 1991.

Cada capítulo apresenta estrutura e conteúdo próprio, conforme os aspectos relevantes do espaço apresentado. Mas esta diversidade não tira solidez e clareza ao livro: o texto é de grande qualidade científica; a ilustração gráfica muito expressiva destacam-se os planos de cidade que, sempre que possível, põem em confronto o mapa de F. Coello, da segunda metade do século XIX, com uma planta funcional muito clara e actualizada. A esta já notável documentação, acrescenta-se quase sempre uma fotografia aérea oblíqua, tirada de baixa altitude, que permite um contacto visual excepcional com o centro urbano e os arredores próximos. Aliás, a qualidade e homogeneidade da ilustração fotográfica é tal que se lamenta faltar neste livro, de preparação tão esmerada, a necessária notícia técnica sobre as condições e datas de realização de um registo aéreo não apenas artístico mas de grande valor científico.

\footnotetext{
${ }^{1}$ Investigadora do Centro de Estudos Geográficos, Faculdade de Letras de Lisboa, Cidade Universitária, 1699 Lisboa Codex. Tel.: (351-1) 7940218; Fax: (351-1) 7938690.

2 Cabero Diéguez, V.; IzQuierdo Misiego, J. I.; José Manuel Llorente Pinto, J. M. (1995) - Salamanca y sus Comarcas. Agedime, S.L. - Editorial Mediterrâneo, Madrid, 360 p.
} 
A província de Salamanca encastoa-se entre as terras do Nordeste de Portugal, ao longo da parte inferior da selvagem garganta do Douro internacional e de uma longa raia seca planáltica. Cobre uma extensão comparável à da região Lisboa e Vale do Tejo, ou a metade das regiões Norte, Centro ou Alentejo. Tal como a faixa interior de Portugal, sofre de despovoamento e envelhecimento, e do abandono acentuado dos seus campos. Com vista a um novo desenvolvimento, a província olha com interesse para a fronteira e sonha em transformar a sua posição excêntrica numa encruzilhada de estradas renovadas: a velha Ruta de la Plata, de orientação meridiana, e o mais longo eixo viário europeu, em boa parte ainda virtual, a E-80, de Helsinki a Lisboa. Os problemas e aspirações salmantinos interessam portanto directamente a Portugal, e a obra dos nossos colegas constitui um exemplo de realização útil e proveitosa. 